Article

\title{
Peptide Extracts from Seven Medicinal Plants Discovered to Inhibit Oomycete Phytophthora infestans, a Causative Agent of Potato Late Blight Disease
}

\author{
Eugene A. Rogozhin 1,2,3,*iD, Alexey S. Vasilchenko ${ }^{4}(\mathbb{D}$, Anna S. Barashkova 1,4, \\ Alexey N. Smirnov ${ }^{5}$, Sergey K. Zavriev ${ }^{1}$ and Vladimir P. Demushkin ${ }^{1,+}$ \\ 1 Shemyakin and Ovchinnikov Institite of Bioorganic Chemistry Russian Academy of Sciences, \\ 117997 Moscow, Russia; barashkova.an@gmail.com (A.S.B.); szavriev@ibch.ru (S.K.Z.) \\ 2 Gause Institute of New Antibiotics, 119021 Moscow, Russia \\ 3 All-Russian Institute of Plant Protection, 196608 St.-Petersburg-Pushkin, Russia \\ 4 Institute of Biological and Agricultural Biology (X-Bio) Tyumen State University, Russian Federation, \\ 625003 Tyumen, Russia; a.s.vasilchenko@utmn.ru \\ 5 Timiryazev Russian State Agrarian University, 127550 Moscow, Russia; smirnov@timacad.ru \\ * Correspondence: rea21@list.ru \\ + Deceased on 6 October 2014.
}

Received: 13 September 2020; Accepted: 24 September 2020; Published: 30 September 2020

check for updates

\begin{abstract}
We report the inhibitory effect of peptide extracts obtained from seven medicinal plants against a causative agent of late blight disease Phytophthora infestans. We find that all the extracts possess inhibitory activity toward the zoospores output, zoosporangium germination, and the development of $P$. infestans on potato disc tubers at different quantitative levels. Based on the biological effects detected, an extract of common horsetail (Equisetum arvense) biomass is recognized as the most effective and is selected for further structural analysis. We perform a combination of amino acid analysis and MALDI-TOF mass spectrometry, which reveal the presence of Asn/Asp- and Gln/Glu-rich short peptides with molecular masses in the range of 500-900 Da and not exceeding $1500 \mathrm{Da}$ as the maximum. Analytical anion-exchange HPLC is successfully applied for separation of the peptide extract from common horsetail (E. arvense). We collect nine dominant components that are combined in two groups with differences in retention times. The $N$-terminal amino acid sequence of the prevalent compounds after analytical ion-exchange HPLC allows us to identify them as peptide fragments of functionally active proteins associated with photosynthesis, aquatic transport, and chitin binding. The anti-oomycete effects may be associated with the conversion of ribulose-1,5-bisphosphate carboxylase/oxygenase to produce a number of biologically active anionic peptides with possible regulatory functions. These data inform our knowledge regarding biologically active peptide fragments; they are the components of programmed or induced proteolysis of plant proteins and can realize secondary antimicrobial functions.
\end{abstract}

Keywords: medicinal plants; amino acid composition; liquid chromatography; anti-oomycete activity; Phytophthora infestans; peptide fragments; protein hydrolysis

\section{Introduction}

Plant diseases caused by oomycetes are a primary problem for agriculture in the world [1]. Late blight disease is one of the most important and dangerous potato and tomato diseases with the potential for practical annihilation of potato plants [2,3]. The pathogen affects plants in damp 
conditions and causes necrosis of the leaves and rapid tuber decomposition [3,4]. Late blight can progress very quickly in both organic and traditional agriculture, even with extensive fungicide application. Phytopathogenic fungi and oomycetes can be killed via alternative agents [5-8] with limited environmental pollution, unlike traditional pesticides. This is important as pathogenic microorganisms have become increasingly resistant to various chemical pesticides.

Renewable resources are generally preferred based on sustainability [9-11]. Many studies have evaluated natural variants regarding the limitation of late blight including antagonistic systems based on the application of other fungal species [12] and the participation of rhizosphere bacteria in the defense system of tomatoes from late blight disease [13-17]. Other approaches are based on the application of micro- and nano-particles from natural polymers to control the oomycete development from the Phytophthora genus $[18,19]$. There are currently many bioactive substances against phytopathogenic organisms, but they do not typically have a stable effect against late blight inhibition [20,21].

Other options include composts [20,22], fungal secondary metabolites [23-26], and plant derivation [27]. Coniferous and flowering plant ethanol extracts [28,29], including lichens [30], have been used also. Crude plant extracts also can have antifungal properties [31-33]. Thus, scientific research on the plant extracts is required to better understand their efficacy and the mechanism to control diseases and insect pests of cultivated plants in the majority of developing countries [34]. The antitumor activity of peptide extracts from medicinal plants was previously shown $[35,36]$. Here, we screen plant peptide extracts that suppress agents of late blight and perform purification and biochemical analysis on the most active variant.

\section{Results}

\subsection{Screening of Plant Peptide Extracts to Suppress Phytophthora infestans In Vitro}

During this study, a number of medicinal plants that are donors of peptide extracts were selected for the following screening against the late blight disease oomycete Phytophthora infestans. Here, we successfully developed a method with limited acid hydrolysis of the total protein content to obtain a standardized composition revealing the biological activity independently. To explore the antimicrobial activity of the peptide extracts, we applied their influence on the indirect and direct germination of $P$. infestans zoosporangia in laboratory conditions using optical microscopy. We performed a two-fold dilution series for experimental measurements of the $\mathrm{IC}_{50}$ and $\mathrm{IC}_{\min }$ values (Table 1 ). The most pronounced inhibition was evaluated using the direct germination of zoosporangia using a growing tube at an $\mathrm{IC}_{\min }$ from 0.25 to $2.0 \mathrm{mg} / \mathrm{mL}$. The mixture of three plants (PE-PM) was two-fold more active $(0.125 \mathrm{mg} / \mathrm{mL})$ than the extracts obtained from the individual plants (PE-Hp and PE-Cs). This displayed an equal activity against indirect germination (output of zoospores from the zoosporangia) compared with the other variants tested to reveal essentially less biological action. The antimicrobial effects of all peptide extracts were lower relative to the direct and indirect oomycete germination $(0.5-2.0 \mathrm{mg} / \mathrm{mL})$ based on the $\mathrm{IC}_{50}$ values; however, the peptide extract in a mixture demonstrated significantly reduced $\mathrm{IC}_{50}$ values $(0.25 \mathrm{mg} / \mathrm{mL})$ (Figure 1$)$.

Table 1. Biological assays of peptide extracts on direct and indirect germination of Phytophthora infestans with application of microtiter-plate assay.

\begin{tabular}{ccccccccc}
\hline \multirow{2}{*}{ Index/Variant } & \multicolumn{7}{c}{ Extract } \\
\cline { 3 - 8 } & & PE-PM & PE-Eqi & PE-Cm & PE-In & PE-Hp & PE-Ln & PE-Cs \\
\hline Indirect & $\mathrm{IC}_{50}, \mathrm{mg} / \mathrm{mL}$ & 0.25 & 1.0 & - & - & 2.0 & - & 2.0 \\
germination & $\mathrm{IC}_{\min }, \mathrm{mg} / \mathrm{mL}$ & 0.125 & 0.5 & - & - & 1.0 & - & 1.0 \\
Direct & $\mathrm{IC}_{50}, \mathrm{mg} / \mathrm{mL}$ & 0.5 & 2.0 & - & 1.0 & 0.5 & - & 0.5 \\
germination & $\mathrm{IC}_{\min }, \mathrm{mg} / \mathrm{mL}$ & 0.125 & 1.0 & 2.0 & 0.5 & 0.25 & 2.0 & 0.25 \\
\multicolumn{2}{l}{ Morphological changes } & + & - & - & - & - & - & - \\
\hline "+"-morphological changes of zoosporangiums: partial destruction and covering lysis at level of $15-18 \%$ at \\
concentration of $2.0 \mathrm{mg} / \mathrm{mL}$.
\end{tabular}



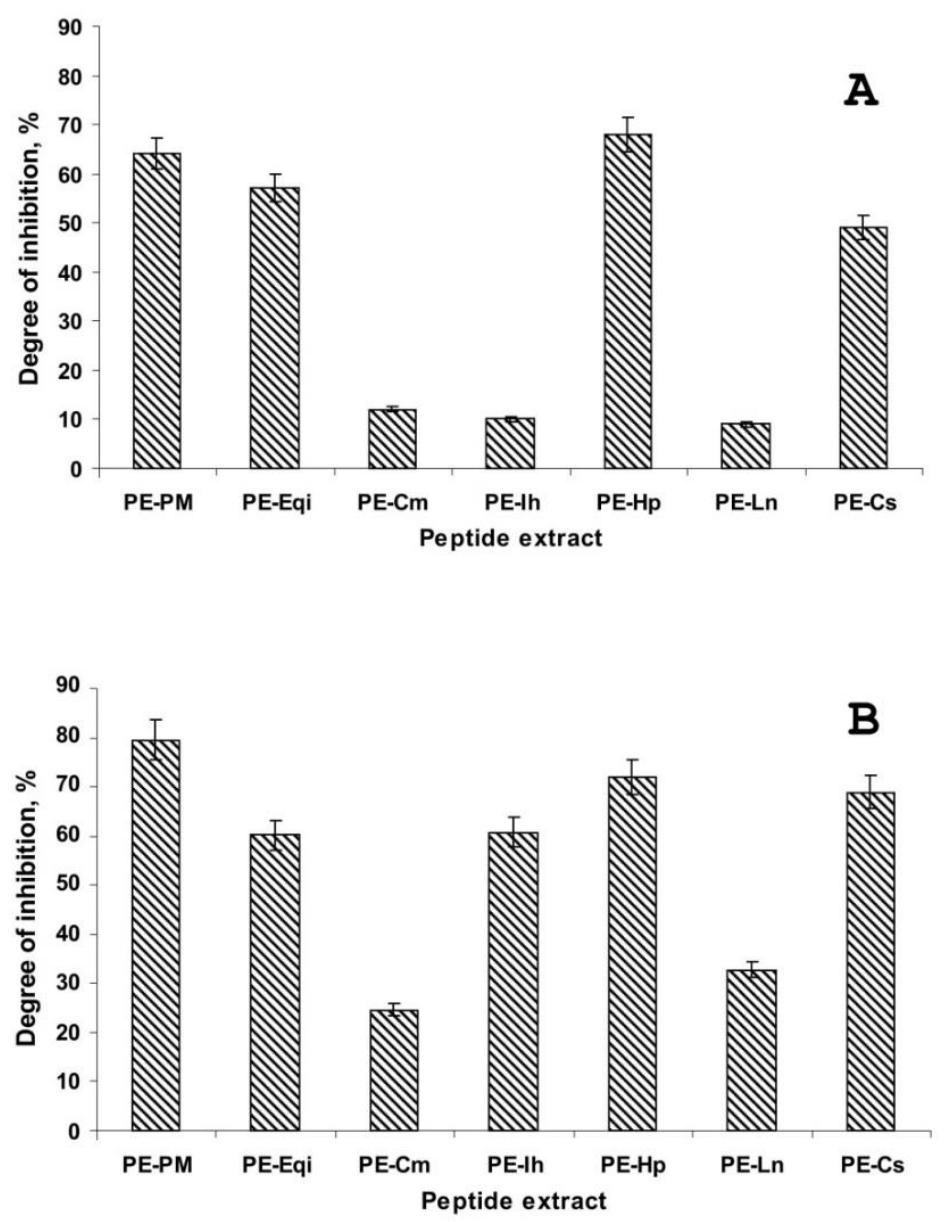

Figure 1. The antimicrobial activity of the plant peptide extracts against Phytophthora infestans by optical microscopy: (A)—indirect germination, (B) - direct germination.

Additionally, some morphological changes of the oomycete structures were observed after incubation with the peptide extracts. The PE-PM at a maximal concentration $(2 \mathrm{mg} / \mathrm{mL})$ caused partial destruction and covering lysis of $18 \%$ fungal cells in the treated sample at a level of $15-18 \%$ (Table 1). However, there was often no deformation of the zoosporangia, zoospores, and mycelium when a single plant extract was added.

\subsection{The Antifungal Activity of Plant Peptide Extracts toward P. infestans by Inoculation of Potato Tuber Discs}

Peptide extracts inhibited P. infestans in vitro at a different level. We evaluated the growth and development of the oomycete when it was inoculated on the surface of potato tuber discs. This method was more objective for understanding the real three-sided interaction between active peptides inside the extracts and understanding the phytopathogen and plant tissue responsible for inoculation from plant innate immunity. The results showed the ability of the peptide extracts to inhibit the appearance of $P$. infestans symptoms (necrotic spots and sporiferous layers) even $96 \mathrm{~h}$ after inoculation: thus, the average area of the potato disc damage was measured to be less than 5\% (excepting PE-Cm and PE-Ih) relative to the control (approximately $20 \%$ of the oomycete development) at the highest concentration tested $(2 \mathrm{mg} / \mathrm{mL}$ ) (Figure 2). PE-Eqi could induce nearly the complete inhibition of $P$. infestans symptoms. After $120 \mathrm{~h}$ of incubation, the peptide extracts retained a degree of inhibition relative to the positive control (approximately $40 \%$ of the oomycete development on the potato disc surface). 


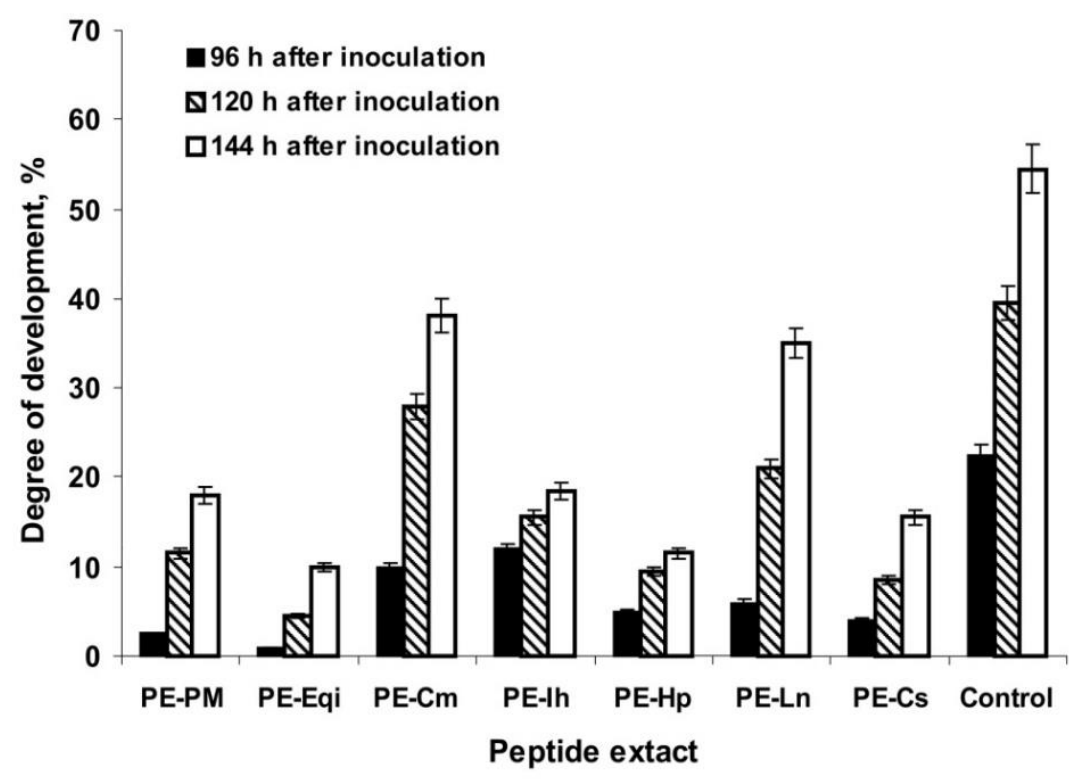

Figure 2. Antimicrobial activity of the plant peptide extracts against $P$. infestans by inoculation of potato tuber slices.

Finally, most variants effectively suppressed P. infestans on the plant tissue within $144 \mathrm{~h}$ of incubation (a final registration point). The peptide extract from common horsetail (E. arvense) revealed the most pronounced effect in a time-dependent manner (Figure 3). Thus, combining the results of two independent assays suggested that the peptide extracts from certain medicinal plants can act toward P. infestans at a different level. This is likely associated with the composition of polypeptides that is unique to each plant.
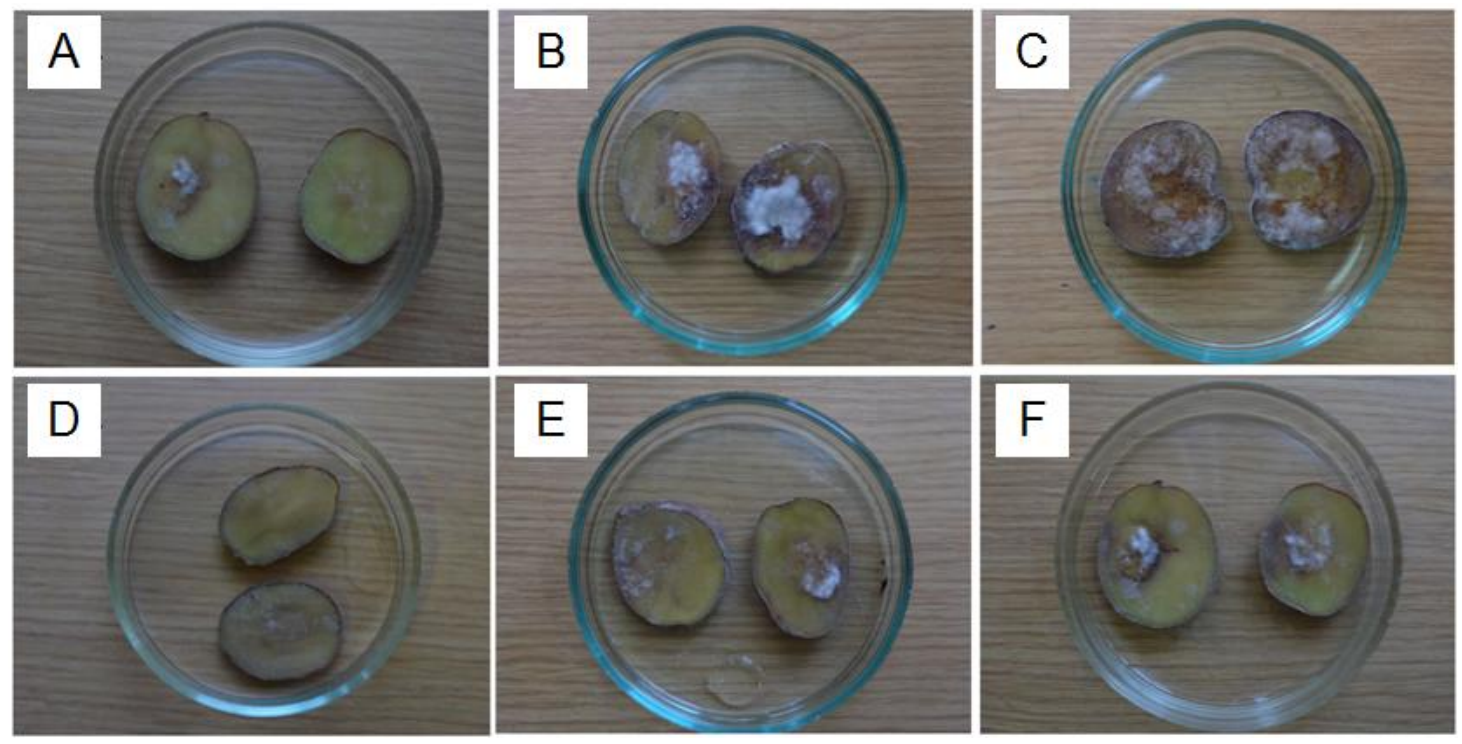

Figure 3. Dynamics of late blight disease development on potato tuber discs: (A)—control since $96 \mathrm{~h}$ after inoculation, (B) - control since $120 \mathrm{~h}$ after inoculation, (C) - control since $144 \mathrm{~h}$ after inoculation; (D)_PE-Eqi since $96 \mathrm{~h}$ after inoculation, (E)_PE-Eqi since $120 \mathrm{~h}$ after inoculation, (F)_PE-Eqi since $144 \mathrm{~h}$ after inoculation.

\subsection{Initial Structural Characterization of PE-Eqi}

Based on the screening results, PE-Eqi from the common horsetail (E. arvense) was selected for further investigation. PE-Eqi had the most pronounced inhibition activity of all individual plants and 
contributed to a high level of activity in the PE-Pm mixture. PE-Eqi was acknowledged to be the most attractive concentrate; it contained a set of polypeptides with the highest activity to suppress $P$. infestans. Thus, it was a resultant candidate to be an active substance for a novel biopesticide. The total yield of polypeptides in this method was $110-120 \mathrm{mg}$ per $100 \mathrm{~g}$ of plant material. The amino acid composition of PE-Eqi led to a significant content of Gln/Glu and Asn/Asp (more than 40\% from the total weight); these were presented as dicarboxylic acids. The total peptide material contained about $90 \%$ of the extract mass. MALDI-MS analysis of the total peptide showed that the most intensive $\mathrm{m} / \mathrm{z}$ signals were measured in the range of 500-900 Da and did not exceed $1500 \mathrm{Da}$ as the maximum (Figure 4). This led to a specified type of limited acidic hydrolysis to obtain reasonably short polypeptides.

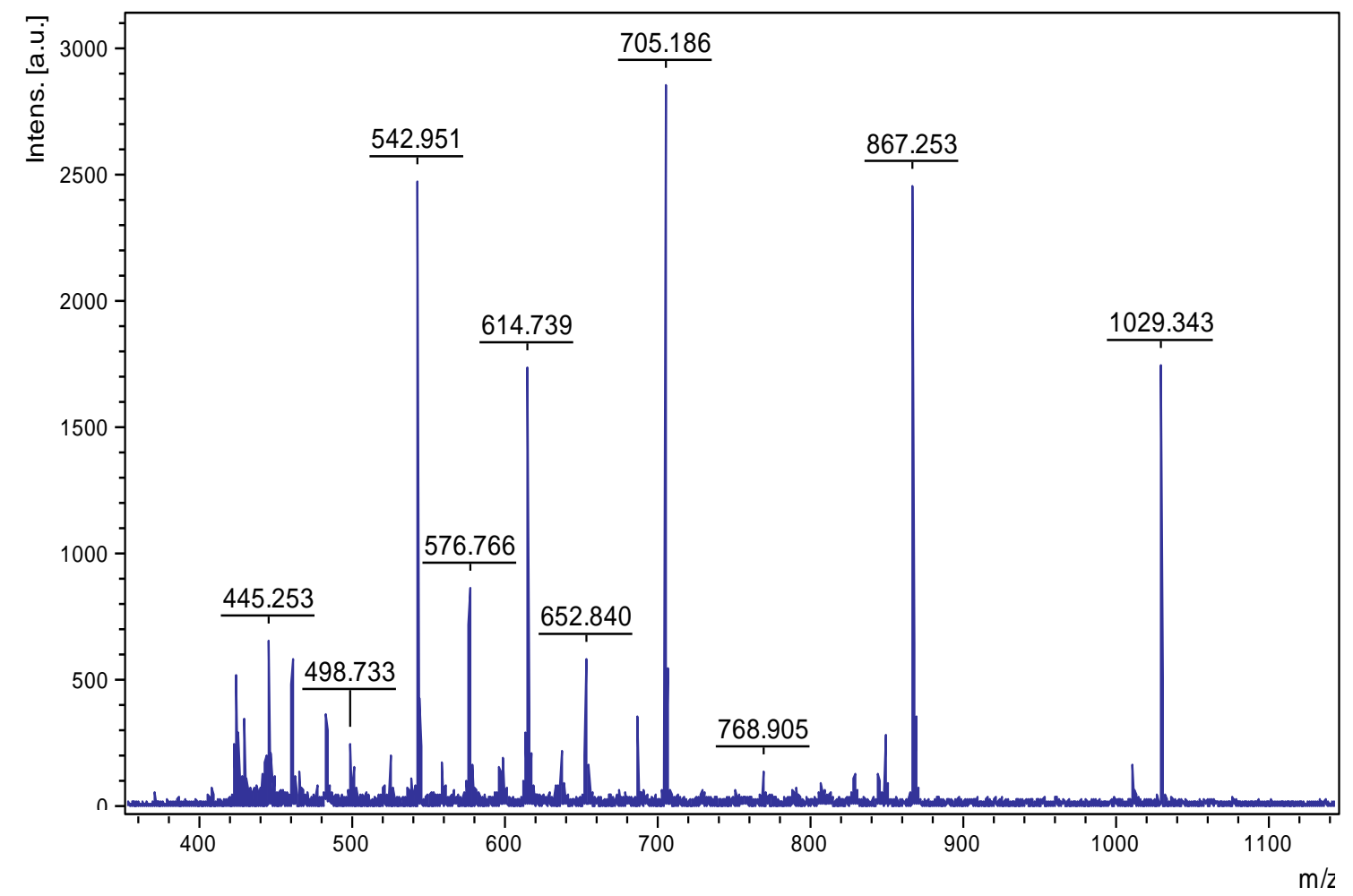

Figure 4. MALDI-TOF MS analysis of the extract from common horsetail (E. arvense). Intens. [a.u.]-intensity of $m / z$ signal, absorption units.

\subsection{HPLC Analysis of PE-Eqi and Structure Determination of Individual Compounds}

The next stage of investigation was to separate the PE-Eqi via analytical HPLC. The peptide extract was initially applied on a reverse-phase column for further fractionation over a linear gradient of organic solvents; however, we did not show any qualitative separation in resolution. Thus, there were only four main peaks visualized in the profile (Figure 5B). Subsequentially, we performed ion-exchange HPLC and attempted to disperse compounds that were localized in the extract using the anion-exchange immobile phase. The amino acid analysis suggested a prevalence of dicarboxylic acids that were negatively charged. Therefore, we could discover individual components combined into the two main groups: high hydrophilic and high hydrophobic (Figure 5A). Thus, nine compounds were manually collected in which four (№ 1-4) were eluted from the column from 10 to 30 min, and five of them (№ 5-9) had a pronounced retention time (65-75 $\mathrm{min})$. 

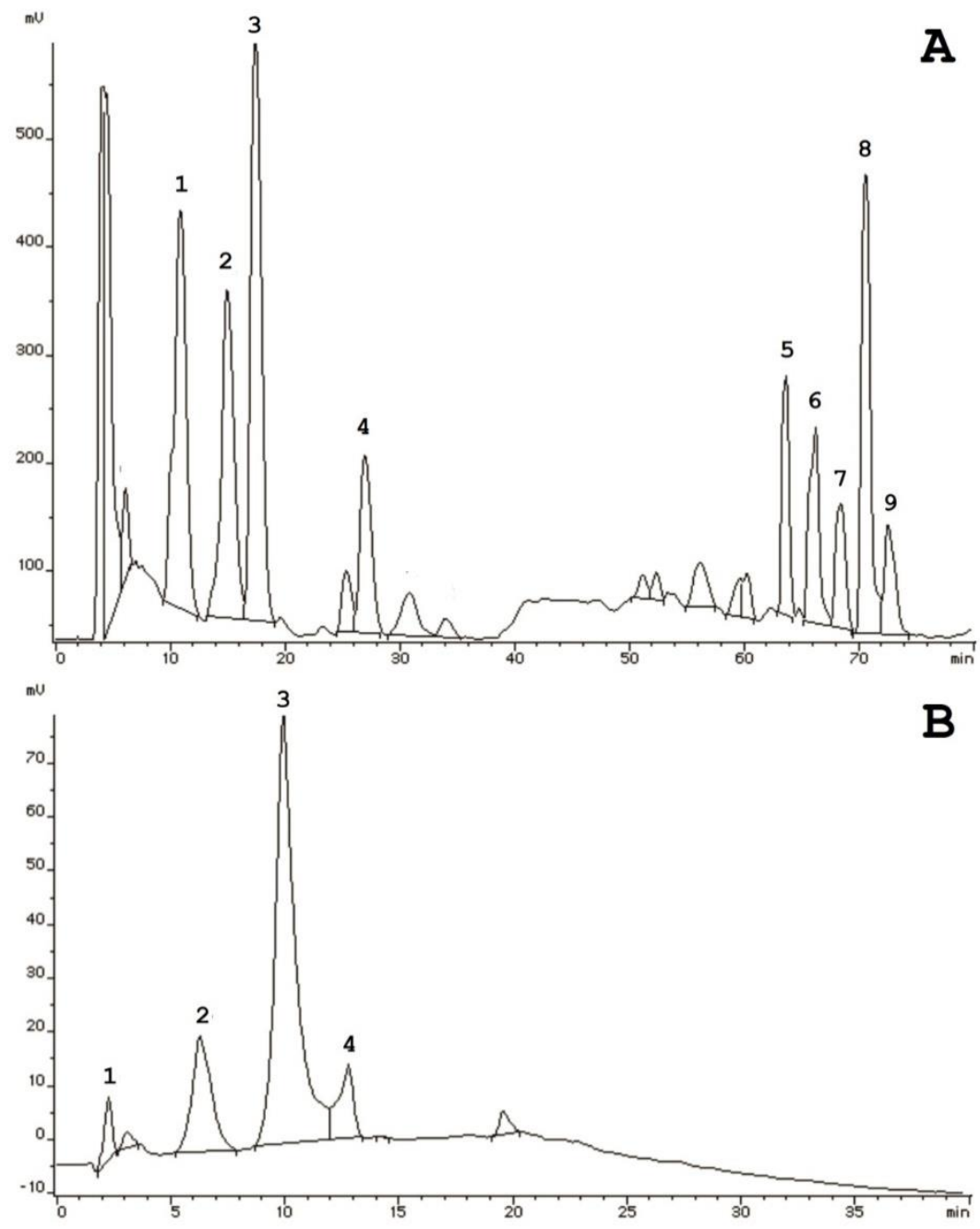

Figure 5. Chromatographic analysis of the PE-Eqi extract: (A)—separation by anion-exchange HPLC, (B)-separation by reversed-phase HPLC.

Our approach could achieve high-resolution separation of the compounds that differed via the presence of negatively charged groups (hypothetically hydroxyls) unlike the separation of hydrophobic liquid chromatography. To provide structural identification of the peptide components located inside the PE-Eqi extract, all samples were manually collected and analyzed with MALDI-TOF MS; N-terminal amino acid sequencing using the Edman automated degradation technique. The sequences were selected for homology searching in NCBI databases using the BLASTP algorithm. The results are presented in Table 2.

We were able to sequence seven from nine components which were short polypeptide chains from 7 to 14 amino acid residues in length. All identified peptides were linear, cysteine-free, and mainly enriched with Asp/Glu as well as polar and non-polar uncharged residues. This was due to the amino acid composition results. Searching for possible homologous sequences among Viridiplantae (taxid: 33,090) in whole, and Equisetum spp. (taxid: 3257) in particular, identified three peptide fragments of ribulose-1,5-bisphosphate carboxylase, a key plant enzyme located in chloroplasts.

There were two short peptide fragments that were homologous to aquaporins and chitinases. These are proteins with defense functions. They are mainly inducible and responsible for external biotic stress, in particular fungal infections by pest damage that have not yet been studied. There were no peptides that could be gene-encoded, only fragments of protein hydrolysis. Finally, the molecular masses were measured for the dominant individual peptides located in a range from 600 to $1500 \mathrm{Da}$, whereas the total peptide extract was composed of 500-900 Da on average. This phenomenon can be 
associated with the ionization peculiarities of the peptides in a mixture compared to the individuals; this was not excluded in the partial fragmentation.

Table 2. A list of peptides identified in the extract from common horsetail (E. arvense).

\begin{tabular}{|c|c|c|c|}
\hline No Peak & $\begin{array}{l}\text { Average Molecular } \\
\text { Mass Measured, Da }\end{array}$ & $\begin{array}{l}N \text {-terminal Amino Acid } \\
\text { Sequence }\end{array}$ & Annotation \\
\hline 1 & 1048.6 & ${ }^{1}$ PAVTLAFATTG ${ }^{11} *$ & Aquaporin product \\
\hline 2 & 905.2 & ${ }^{1}$ PSGGALNY8 & Unidentified protein product \\
\hline 3 & 1160.4 & ${ }^{1}$ PVAGEDNQFLA $^{11}$ & $\begin{array}{c}\text { Ribulose-1,5-bisphosphate } \\
\text { carboxylase/oxygenase large } \\
\text { subunit fragment }\end{array}$ \\
\hline 4 & 615.2 & No sequence determined & - \\
\hline 5 & 943.5 & ${ }^{1} \mathrm{DFYRDND}^{7}$ & $\begin{array}{l}\text { Possible hypothetical chloroplast } \\
\text { RF21 protein fragment }\end{array}$ \\
\hline 6 & 1378.2 & ${ }^{1}$ DLIRDDFIEKD $^{11}$ & $\begin{array}{c}\text { Ribulose-1,5-bisphosphate } \\
\text { carboxylase/oxygenase large } \\
\text { subunit fragment }\end{array}$ \\
\hline 7 & 1471.8 & ${ }^{1}$ QYQLDGIDLDYE ${ }^{12}$ & Chitinase A fragment \\
\hline 8 & 1010.1 & ${ }^{1}$ DFTRDDEN $^{8}$ & $\begin{array}{l}\text { Possible ribulose-1,5-bisphosphate } \\
\text { carboxylase/oxygenase large } \\
\text { subunit fragment }\end{array}$ \\
\hline 9 & 722.8 & No sequence determined & - \\
\hline
\end{tabular}

* A number of amino acid residues in $N$-terminal sequences is marked by superscript.

\section{Discussion}

Here, we studied plant peptide extracts for activity against potato late blight. We used partial acidic hydrolysis to obtain short peptides with relatively predetermined molecular masses. These peptide extracts were previously shown to have cytotoxic and antitumor activities in vitro and in vivo models [35,36]. The main functional aspect of this study consisted of screening these extracts for inhibition activity toward oomycete P. infestans-the causative agent of potato and tomato late blight-which is one of the most economically important crop diseases leading to significant losses of plant production annually around the world [37].

Considering this, natural target extracts obtained from accessible plant species are potentially good additions to chemical fungicides to decrease the residual quantities inside the final production of plant cultivation and the environment as a whole, and to make the technology of integrated plant protection less expensive. Our findings show that peptide extracts against $P$. infestans, as determined by optical microscopy, had a high level of inhibition. There are some mentions confirming the application of aquatic and organic plant extracts to suppress $P$. infestans and other phytopathogenic oomycetes; these are potent agents for biocontrol [38-41]. Generally, the target activity is associated with secondary metabolites of a different chemical nature and not with polypeptides.

It is typical to provide testing of the anti-oomycete activity of the peptide extracts to suppress the growth and development of $P$. infestans, including infection of the potato tuber surface. We could not confirm the same results; only a limited number of extracts displayed a strong level of pathogen deterrence in a time-dependent manner. These results are not surprising because the addition of plant tissue (slices of potato tubers) to the experiment led to the appearance of molecular interactions between the plant, its specific pathogen, and the external agent (a peptide extract). The activity was less effective because $P$. infestans could increase in the virulence level.

Several studies reported the molecular mechanisms of the Solanaceae plant's resistance to $P$. infestans based on genomic and transcriptomic data analysis [42,43], the expression of genes encoding matrix metalloproteinases, the miRNA [44-46], and the inducible gene expression coding PR-proteins [47-49]. Taking another view, P. infestans is known to infect plant hosts that can realize protein virulence factors and that are activated in contact with a plant surface. These factors are enzymes 
(cyclophilins, phospholipases, and cutinases) [50-52], certain extracellular proteins that are represented by serine- and metalloproteinases [53], and a widely represented class of infection-associated effector proteins (with an $N$-terminal RXLR motif) [54,55].

We note that all antimicrobial peptide extracts were obtained via the efficient method of peptide material extraction. This provided a nearly complete absence of certain admixtures, including carbohydrates, bioflavonoids, steroids, glycosides, vitamins, and other theoretical dissoluble natural secondary metabolites [36]. Thus, all peptide extracts obtained using this original method were reproduced on their composition. These findings might have commercial value in the case of potential applications in industry.

The peptide extract isolated from common horsetail (E. arvense) demonstrated the most pronounced suppression of $P$. infestans compared to the other plants via two independent assays. This plant is primitive and ancient and belongs to the Equisetaceae family from the Polypodiophyta division. It is a good source of natural compounds, including antioxidants [56], flavonoids [57], and biologically-active carbohydrates [58]. E. arvense is a model object to isolate for the structural analysis of key proteins involved in the plant metabolism, including ferredoxin I and II isoforms [59], and cytochrome $c$ reductase [60]. There currently is not any peptide isolated from common horsetail reported, including antimicrobials.

Previous authors reported that ethanolic extracts from E. arvense induced anticancer effects to suppress lung carcinoma cells at 100-150 $\mu \mathrm{g} / \mathrm{mL}$ [61]. Hydroethanolic extracts were more effective as antinociceptive and anti-inflammatory agents in mice [62] and had a negative influence on Aspergillus flavus and Fusarium verticillioides; these produce mycotoxins in stored maize kernels (Zea mays) [63]. Aquatic extracts of E. arvense could possess antibacterial action toward clinical Escherichia coli involving the disruption of the biofilm formation [64].

Our results are the first mention that antimicrobial substances derived from $E$. arvense are peptides. A comparison of reversed-phase and anion-exchange HPLC for the isolation of compounds from the E. arvense peptide extract suggested that they are relatively hydrophilic and enriched by negatively charged amino acid residues. The active peptide extract contained a set of major components-the majority of which were fragments of partial hydrolysis of chloroplast proteins. Inside the extract, we identified peptide fragments that were members of the three main groups of plant proteins: aquaporins [65], chitinase A [66], and ribulose-1,5-bisphosphate carboxylase/oxygenase (Rubisco) [67].

Plant chitinases are known to have defense functions and are responsible for biotic stresses; however, the enzyme from common horsetail (E. arvense) belongs to class IIIb, for which no antifungal activity was detected. Thus, we may suppose that the antitumor activity previously detected [36], as well as the anti-oomycete effect described in this work may be associated with the target conversion of Rubisco to produce a number of biologically active anionic peptides with possible regulatory functions.

\section{Materials and Methods}

\subsection{Medicinal Plants}

To screen for antifungal activity in vitro, we selected plants used in traditional medicine: greater celandine (Chelidonium majus), PE-Cm; elecampane (Inula helertium), PE-Ih; common horsetail (Equisetum arvense), PE-Eqi; sweet bay (Laurus nobilis), PE-Ln; green tea (Camellia sinensis), PE-Cs; touch-and-heal (Hypericum perforatum), PE-Hp; and a mixture of the three plants combined (elecampane, greater celandine, and common horsetail), PE-Pm. Initially, all plant raw material was collected manually mboxciteB35-plants-948139,B68-plants-948139.

\subsection{Oomycete Origin and Cultivation Conditions}

The oomycete P. infestans strain OSV 12 was received from the Institute of Plant Protection (Priluki, Minsk District, the Republic of Belarus). Colonies of P. infestans were being grown in oat nutrient growth medium at the temperature of $14-16{ }^{\circ} \mathrm{C}$ for $12-14$ days. 


\subsection{Peptide Extracts}

To obtain the peptide extracts, the original procedure was performed to remove all high-molecular weight components (preliminary proteins and carbohydrates) and secondary metabolites. Taking $10 \mathrm{~g}$ of the raw plant, over ground material, was ground, soaked in $500 \mathrm{~mL}$ of $1 \mathrm{M}$ acetic acid (Merck, Darmstadt, Germany), and left for $1 \mathrm{~h}$ at room temperature. During the exposition, the suspension was obtained using ultrasonication (five times through $10 \mathrm{~min}$ ). Subsequently, the suspension was heated at $100{ }^{\circ} \mathrm{C}$ for $30 \mathrm{~min}$, cooled, and centrifuged $(75,000 \times \mathrm{g}, 40 \mathrm{~min}$, using a J2-21 (Beckman, Krefeld, Germany). Acetone was added to collect the supernatant at a ratio of 2:5 and precipitated at $+4{ }^{\circ} \mathrm{C}$ overnight. Then, a pellet was separated by centrifugation $(40,000 \times g, 40 \mathrm{~min}, \mathrm{~J} 2-21$ (Beckman, Germany). To improve the dissolving of a peptide extract, the pellet was dissolved in $100 \mathrm{mM}$ acetic acid and repeatedly centrifuged (twice, 40,000 $\times g, 20 \mathrm{~min}$ ). To remove residual acidic quantities, the pellet was lyophilized twice by dissolving in $50 \mathrm{~mL}$ of MQ water.

\subsection{Amino Acid Analysis}

The amino acid composition was determined as described previously [36]. The analysis was performed on a Biotronik LC-3000 amino acid analyzer (Biotronik, Berlin, Germany). Regarding each reaction, $300 \mu \mathrm{g}$ of the extract was selected for further acidic hydrolysis. Ion exchange HPLC was performed on a LC 3000 amino acid analyzer (Biotronik, Berlin, Germany). The peptide extracts were dissolved in $60 \mu \mathrm{L}$ of a buffer containing $0.82 \mathrm{~g}$ of sodium acetate, $75 \mathrm{~mL}$ of methanol, $0.5 \mathrm{~mL}$ of glacial acetic acid, $100 \mu \mathrm{L}$ of caprylic acid, and $10 \%$ formic acid in $1 \mathrm{~L}$ (solvent $\mathrm{A}$ ), where the concentration of the peptide extracts was $10 \mathrm{mg} / \mathrm{mL}$, and applied in a $1.0 \times 125 \mathrm{~mm}$ column with VT-2410 resin (Biotronik, Berlin, Germany) equilibrated with solvent A.

Concerning elution, we used: solvent $\mathrm{A}$, containing $1 \mathrm{~g}$ of $8.2 \mathrm{~g}$ of sodium acetate, $75.0 \mathrm{~mL}$ of methanol, $5.0 \mathrm{~mL}$ of glacial acetic acid, $4.0 \mathrm{~mL}$ of formic acid, and $100 \mu \mathrm{L}$ of caprylic acid, $\mathrm{pH} 3.3$; buffer containing $1 \mathrm{~L} 4.0 \mathrm{~g}$ of sodium hydroxide, $2.7 \mathrm{~mL}$ of glacial acetic acid, $2.5 \mathrm{~mL}$ of formic acid, and $100 \mu \mathrm{L}$ of caprylic acid, $\mathrm{pH} 3.6$ (solvent B); buffer containing $4.0 \mathrm{~g}$ of sodium hydroxide in $1 \mathrm{~L}$, $2.7 \mathrm{~mL}$ of glacial acetic acid, $2.5 \mathrm{~mL}$ of formic acid, and $100 \mu \mathrm{L}$ of caprylic acid, $\mathrm{pH} 4.9$ (solvent C); and buffer containing $1 \mathrm{~L}$ of $1.0 \mathrm{~mL}$ of glacial acetic acid, $83 \mathrm{mM}$ trisodium phosphate, $1.0 \mathrm{~g}$ EDTA, and $100 \mu \mathrm{L}$ caprylic acid, $\mathrm{pH} 10.5$ (solvent $\mathrm{D}$ ). The samples were eluted sequentially with solvents $\mathrm{A}$ $\left(30.5 \mathrm{~min}\right.$ at $\left.40^{\circ} \mathrm{C}\right), \mathrm{B}\left(7.5 \mathrm{~min}\right.$ at $\left.60^{\circ} \mathrm{C}\right), \mathrm{C}\left(12 \mathrm{~min}\right.$ at $\left.60^{\circ} \mathrm{C}\right)$, and $\mathrm{D}\left(27 \mathrm{~min}\right.$ at $\left.60^{\circ} \mathrm{C}\right)$ at a flow rate of $0.2 \mathrm{~mL} / \mathrm{min}$. To visualize, a ninhydrin solution containing $20 \mathrm{~g}$ of ninhydrin, $0.6 \mathrm{~g}$ of hydrindantin din, $50 \mathrm{~mL}$ of phenol, $550 \mathrm{~mL}$ of ethylene glycol monomethyl ether, and $400 \mathrm{~mL}$ of $4 \mathrm{M}$ sodium acetate (pH 5.5) was used. The detection was monitored at $570 \mathrm{~nm}$.

\subsection{MALDI TOF Mass Spectrometry}

The mass spectra were measured using an Ultraflex TOF/TOF instrument (Bruker, Berlin, Germany) in a positive ion mode. The peptide extracts were dissolved in $30 \% \mathrm{MeCN}$ at a final concentration of about 500 pmoles $/ \mu \mathrm{L}$, and $1 \mu \mathrm{L}$ was mixed with an equal volume of a matrix (2,5-dihydroxybensoic acid) (Merck, Kenilworth, NJ, USA), dried in air prior to analysis. The data obtained were processed with FlexAnalysis software.

\subsection{Ion-Exchange HPLC}

Ion-exchange separation was provided using the Agilent 1200 Series (Agilent Technologies, Santa Clara, CA, USA). The peptide extracts $(0.5 \mathrm{mg})$ were dissolved in $50 \mu \mathrm{L}$ of $50 \mathrm{mM}$ PBS buffer ( $\mathrm{pH}$ 8.0) and applied on a Luna SAX $4 \times 250 \mathrm{~mm}$ column (Phenomenex, Torrance, CA, USA) equilibrated with the same solvent (buffer A). Peptides were eluted from the column using a linear gradient of buffer $\mathrm{B}$ (PBS and $500 \mathrm{mM} \mathrm{NaCl}, \mathrm{pH} 8.0$ ) at a flow rate of $1.0 \mathrm{~mL} / \mathrm{min}$. UV detection was monitored at $220 \mathrm{~nm}$. 


\subsection{Reversed-Phase HPLC}

To perform RP-HPLC, a Du Pont 8800 instrument (Du Pont, Wilmington, DE, USA) was used. The peptide extracts $(0.5 \mathrm{mg})$ were dissolved in $50 \mu \mathrm{L}$ of $0.1 \%$ trifluoroacetic acid (TFA) and applied on a Nucleosil $^{\circledR}$ 5/C18 $4 \times 250$ mm column (Macherey-Nagel GmbH and Co, Düren, Germany) equilibrated with $0.1 \%$ TFA (buffer A). The peptides were eluted from the column using a linear gradient of buffer $\mathrm{B}(80 \% \mathrm{MeCN}, 0.1 \% \mathrm{TFA})$ at a flow rate of $1.0 \mathrm{~mL} / \mathrm{min}$. The UV detection was monitored at $220 \mathrm{~nm}$ (Uvicord SII detector, GE HealthCare, Madison, WI, USA).

\subsection{Edman Sequencing}

$N$-terminal amino acid sequencing was conducted on a PPSQ-33A sequencer (Shimadzu, Kyoto, Japan) according to the manufacturer's protocol. Approximately 500 pmoles of each compound purified by HPLC was analyzed. The identification of amino acid residues was performed using PTH derivatives using LabSolutions software.

\subsection{Antifungal Assays In Vitro}

The antifungal activity of the peptide extracts was tested using a microtiter-plate assay by measuring the inhibition of the germination of zoosporangiums as described [69]. Two-fold dilutions of extracts in pure water were prepared (from 2000 to $125 \mu \mathrm{g} \cdot \mathrm{mL}^{-1}$ ) and added to the zoosporangium suspension in the water, containing, on average, from 5000 cells/mL. The plates were incubated at $15^{\circ} \mathrm{C}$ and scored after $4 \mathrm{~h}$ (output of zoospores/direct germination) and $48 \mathrm{~h}$ (zoosporangium germination/indirect germination). Inhibition of the zoospores output (indirect germination) was estimated as the number of remaining zoospores relative to the total number (Each replicate is represented by calculation of cell quantity on 10 visual fields at optical microcopy). The inhibition of zoosporangium germination (direct germination) was estimated as the number of germinated zoosporangiums relative to their total number. These rates were expressed in ICmin (effect of inhibition more than $15 \%$ ) and $\mathrm{IC}_{50}$ values showing the plant extract concentration required for the growth inhibition of $50 \%$ of the remaining zoospores or zoosporangium. The morphological changes in the microorganisms also were recorded. The experiments were conducted using two biological repetitions in three replicates of each variant.

\subsection{Antifungal Assay by Inoculation of Potato Tuber Discs}

The biological activity of peptide extracts also was assayed by estimating the degree of inhibition of $P$. infestans development on potato tuber discs [70]. Two potato tuber discs of similar size were placed in each Petri dish. The peptide samples were mixed with $50 \mu \mathrm{L}$ of zoosporangium suspension in distilled water (at an average of 5000 zoosporangiums $\mathrm{mL}^{-1}$ ) to a final peptide extract concentration of $0.125-2.0 \mathrm{mg} / \mathrm{mL}$ and incubated at $20{ }^{\circ} \mathrm{C}$ for $2 \mathrm{~h}$. The plant extract sample was applied to the center of each potato tuber disc. Potato discs infected with the zoosporangium suspension without peptide extract served as controls. The Petri dishes with infected potato tuber discs were incubated at $20{ }^{\circ} \mathrm{C}$ for $120 \mathrm{~h}$. The disease severity was assayed 96,120 , and $144 \mathrm{~h}$ after inoculation by measuring the infected area of each disc and scored, denoting the absence of inhibition compared with the controls. A degree of infection is determined by comparison of a relative square of damage according to a full square of a tuber disc based on Abode Photoshop for Windows software. Ten discs were analyzed in each of three independent experiments.

Author Contributions: Conceptualization, E.A.R., V.P.D.; methodology, E.A.R., A.S.B., A.N.S.; software, V.P.D.; validation, E.A.R., S.K.Z.; formal analysis, E.A.R., A.S.V.; data curation, E.A.R., A.S.B.; writing一original draft preparation, E.A.R., A.S.V.; writing—review and editing, E.A.R., A.S.V., A.S.B., S.K.Z.; visualization, E.A.R., A.S.B., S.K.Z.; supervision, E.A.R., V.P.D.; project administration, E.A.R.; funding acquisition, E.A.R. All authors have read and agreed to the published version of the manuscript.

Funding: This study is supported by the Russian Science Foundation (grant № 19-76-30005) (section devoted to antimicrobial activity of the plant peptide extracts against Phytophthora infestans) and the Russian Foundation for 
Basic Research (grant № 18-34-20058) (section devoted to structural analysis of the peptide extract from common horsetail (Equisetum arvense) and fractionating by HPLC).

Acknowledgments: The authors are grateful to Inna I. Tepkeeva (from the Laboratory of Peptide Chemistry Shemyakin and Ovchinnikov Institute of Bioorganic Chemistry) for help in obtaining the plant peptide extracts, and Dmitry Zaytsev (from the Department of Plant Protection, the Sector of Agricultural Phytopathology Timiryazev Moscow State Agrarian University) for fruitful discussions and advises concerning antimicrobial assays).

Conflicts of Interest: The authors declare no conflict of interest.

\section{Abbreviations}

MALDI-TOFmatrix-assisted laser desorption/ionization time-of-flight mass

MS spectrometry

Asn asparagine

Asp aspartate

Gln glutamine

Glu glutamate

HPLC high performance liquid chromatography

IC50 inhibition concentration caused half-effect

ICmin inhibition concentration caused sub-effect (15\%);

NCBI National Center of Biotechnology Information, USA

BLASTP basic local alignment search tool protein;

MQ deionized water

EDTA ethylenediaminetetraacetic acid

PBS phosphate-buffered saline

$\mathrm{NaCl}$ sodium chloride

UV ultraviolet

RP-HPLC reversed-phase high performance liquid chromatography;

$\mathrm{MeCN} \quad$ acetonitrile

PTH phenylthiohydantoin

\section{References}

1. Gisi, U.A.L. Advances in Downy Mildew Research; Kluwer Academic Publishers: Dordrecht, The Netherlands, 2002.

2. Leesutthiphonchai, W.; Vu, A.L.; Ah-Fong, A.M.V.; Judelson, H.S. How Does Phytophthora infestans Evade Control Efforts? Modern Insight into the Late Blight Disease. Phytopathology 2018, 108, 916-924. [CrossRef] [PubMed]

3. Wang, W.; Jiao, F. Effectors of Phytophthora pathogens are powerful weapons for manipulating host immunity. Planta 2019, 250, 413-425. [CrossRef] [PubMed]

4. Stephan, D.; Eckhard, K. Screening of plant extracts, rnicro-organisms and commercial preparations for biocontrol of Phytophthora infestans on detached potato leaves. IOBC WPRS Bull. 2006, 25, 391-394.

5. Fravel, D.R.; Connick, W.J.; Lewis, J.A. Formulation of Microorganisms to Control Plant Diseases. In Formulation of Microbial Biopesticides; Springer Nature: Dordrecht, The Netherlands, 1998; pp. 187-202.

6. Stephan, D.; Schmitt, A.; Martins Carvalho, S.; Seddon, B.; Koch, E. Evaluation of biocontrol preparations and plant extracts for the control of Phytophthora infestans on potato leaves. Eur. J. Plant Pathol. 2005, 112, 235-246. [CrossRef]

7. Kamoun, S.; Furzer, O.; Jones, J.D.G.; Judelson, H.S.; Ali, G.S.; Dalio, R.J.D.; Roy, S.G.; Schena, L.; Zambounis, A.; Panabières, F.; et al. The Top 10 oomycete pathogens in molecular plant pathology. Mol. Plant Pathol. 2015, 16, 413-434. [CrossRef]

8. Fry, W.E. Phytophthora infestans: New Tools (and Old Ones) Lead to New Understanding and Precision Management. Annu. Rev. Phytopathol. 2016, 54, 529-547. [CrossRef]

9. Quimby, P.C.; King, L.R.; Grey, W.E. Biological control as a means of enhancing the sustainability of crop/land management systems. Agric. Ecosyst. Environ. 2002, 88, 147-152. [CrossRef]

10. Andreu, A.B.; Guevara, M.G.; Wolski, E.A.; Daleo, G.R.; Caldiz, D.O. Enhancement of natural disease resistance in potatoes by chemicals. Pest Manag. Sci. 2006, 62, 162-170. [CrossRef] 
11. Chen, F.; Zhou, Q.; Qin, C.; Li, Y.; Zhan, J. Low evolutionary risk of iprovalicarb resistance in Phytophthora infestans. Pestic. Biochem. Physiol. 2018, 152, 76-83. [CrossRef]

12. Jindal, K.K.; Singh, H.; Meeta, M. Biological control of Phytophthora infestans on potato. Indian J. Plant Pathol. 1988, 6, 59-62.

13. Yan, Z.; Reddy, M.S.; Ryu, C.M.; McInroy, J.A.; Wilson, M.; Kloepper, J.W. Induced systemic protection against tomato late blight elicited by plant growth-promoting rhizobacteria. Phytopathology 2002, 92, 1329-1333. [CrossRef] [PubMed]

14. Lamsal, K.; Kim, S.W.; Kim, Y.S.; Lee, Y.S. Biocontrol of late blight and plant growth promotion in tomato using rhizobacterial isolates. J. Microbiol. Biotechnol. 2013, 23, 897-904. [CrossRef] [PubMed]

15. Tomar, S.; Singh, B.P.; Lal, M.; Khan, M.A.; Hussain, T.; Sharma, S.; Kaushik, S.K.; Kumar, S. Screening of novel microorganisms for biosurfactant and biocontrol activity against Phytophthora infestans. J. Environ. Biol. 2014, 35, 893-899. [PubMed]

16. Cray, J.A.; Connor, M.C.; Stevenson, A.; Houghton, J.D.R.; Rangel, D.E.N.; Cooke, L.R.; Hallsworth, J.E. Biocontrol agents promote growth of potato pathogens, depending on environmental conditions. Microb. Biotechnol. 2016, 9, 330-354. [CrossRef] [PubMed]

17. De Vries, S.; von Dahlen, J.K.; Schnake, A.; Ginschel, S.; Schulz, B.; Rose, L.E. Broad-spectrum inhibition of Phytophthora infestans by fungal endophytes. FEMS Microbiol. Ecol. 2018, 94, 1-15. [CrossRef]

18. Ali, M.; Kim, B.; Belfield, K.D.; Norman, D.; Brennan, M.; Ali, G.S. Inhibition of Phytophthora parasitica and P. capsici by silver nanoparticles synthesized using aqueous extract of Artemisia absinthium. Phytopathology 2015, 105, 1183-1190. [CrossRef]

19. Divya, K.; Smitha, V.; Jisha, M.S. Antifungal, antioxidant and cytotoxic activities of chitosan nanoparticles and its use as an edible coating on vegetables. Int. J. Biol. Macromol. 2018, 114, 572-577. [CrossRef]

20. Ghorbani, R.; Wilcockson, S.; Leifert, C. Alternative treatments for late blight control in organic potato: Antagonistic micro-organisms and compost extracts for activity against Phytophthora infestans. Potato Res. 2005, 48, 181-189. [CrossRef]

21. Wianowska, D.; Garbaczewska, S.; Cieniecka-Roslonkiewicz, A.; Dawidowicz, A.L.; Jankowska, A. Comparison of antifungal activity of extracts from different Juglans regia cultivars and juglone. Microb. Pathog. 2016, 100, 263-267. [CrossRef]

22. Cayuela, M.L.; Millner, P.D.; Meyer, S.L.F.; Roig, A. Potential of olive mill waste and compost as biobased pesticides against weeds, fungi, and nematodes. Sci. Total Environ. 2008, 399, 11-18. [CrossRef]

23. Kang, S.W.; Kim, S.W. New antifungal activity of penicillic acid against Phytophthora species. Biotechnol. Lett. 2004, 26, 695-698. [CrossRef] [PubMed]

24. Son, S.W.; Kim, H.Y.; Choi, G.J.; Lim, H.K.; Jang, K.S.; Lee, S.O.; Lee, S.; Sung, N.D.; Kim, J.C. Bikaverin and fusaric acid from Fusarium oxysporum show antioomycete activity against Phytophthora infestans. J. Appl. Microbiol. 2008, 104, 692-698. [CrossRef]

25. Wang, G.; Liu, Z.; Lin, R.; Li, E.; Mao, Z.; Ling, J.; Yang, Y.; Yin, W.B.; Xie, B. Biosynthesis of Antibiotic Leucinostatins in Bio-control Fungus Purpureocillium lilacinum and Their Inhibition on Phytophthora Revealed by Genome Mining. PLoS Pathog. 2016, 12, e1005685. [CrossRef]

26. Dahlin, P.; Müller, M.C.; Ekengren, S.; McKee, L.S.; Bulone, V. The impact of steroidal glycoalkaloids on the physiology of Phytophthora infestans, the causative agent of potato late blight. Mol. Plant Microbe Interact. 2017, 30, 531-542. [CrossRef] [PubMed]

27. Portz, D.; Koch, E.; Slusarenko, A.J. Effects of garlic (Allium sativum) juice containing allicin on Phytophthora infestans and downy mildew of cucumber caused by Pseudoperonospora cubensis. Eur. J. Plant Pathol. 2008, 122, 197-206. [CrossRef]

28. Kim, J.C.; Choi, G.J.; Lee, S.W.; Kim, J.S.; Chung, K.Y.; Cho, K.Y. Screening extracts of Achyranthes japonica and Rumex crispus for activity against various plant pathogenic fungi and control of powdery mildew. Pest Manag. Sci. 2004, 60, 803-808. [CrossRef]

29. Manter, D.K.; Kelsey, R.G.; Karchesy, J.J. Antimicrobial activity of extractable conifer heartwood compounds toward Phytophthora ramorum. J. Chem. Ecol. 2007, 33, 2133-2147. [CrossRef]

30. Halama, P.; Van Haluwin, C. Antifungal activity of lichen extracts and lichenic acids. BioControl 2004, 49, 95-107. [CrossRef] 
31. Blaeser, P.; Steiner, U.; Lyr, H.; Russel, P.E.; Dehne, H.W.; Sisler, H.D. Antifungal activity of plant extracts against potato late blight (Phytophthora infestans). In Modern fungicides and antifungal compounds II, Proceedings of the 12th International Reinhardsbrunn Symposium, Friedrichroda, Thuringia, Germany, 24-29 May 1998; Intercept: New York, NY, USA, 1999; pp. 491-499.

32. Pretorius, J.C.; Zietsman, P.C.; Eksteen, D. Fungitoxic properties of selected South African plant species against plant pathogens of economic importance in agriculture. Ann. Appl. Biol. 2002, 141, 117-124. [CrossRef]

33. Okemo, P.O.; Bais, H.P.; Vivanco, J.M. In vitro activities of Maesa lanceolata extracts against fungal plant pathogens. Fitoterapia 2003, 74, 312-316. [CrossRef]

34. Dales, M.J. A review of plant material used for controlling insect pests of stored products. Nat. Resour. Inst. Bull. 1996, 65, 1-91.

35. Chaadaeva, A.V.; Tepkeeva, I.I.; Moiseeva, E.V.; Svirshchevskaya, E.V.; Demshkin, V.P. Antitumor activity of the plant remedy peptide extract pe-pm in a new mouse t-lymphoma/leukemia model. Biomeditsinskaya Khimiya 2009, 55, 81-88.

36. Tepkeeva, I.I.; Moiseeva, E.V.; Chaadaeva, A.V.; Zhavoronkova, E.V.; Kessler, Y.V.; Semushina, S.G.; Demushkin, V.P. Evaluation of antitumor activity of peptide extracts from medicinal plants on the model of transplanted breast cancer in CBRB-Rb(8.17)1Iem mice. Bull. Exp. Biol. Med. 2008, 145, 464-466. [CrossRef] [PubMed]

37. Rakotonindraina, T.; Chauvin, J.É.; Pellé, R.; Faivre, R.; Chatot, C.; Savary, S.; Aubertot, J.N. Modeling of yield losses caused by potato late blight on eight cultivars with different levels of resistance to phytophthora infestans. Plant Dis. 2012, 96, 935-942. [CrossRef] [PubMed]

38. Choi, N.H.; Jang, J.Y.; Choi, G.J.; Choi, Y.H.; Jang, K.S.; Nguyen, V.T.; Min, B.S.; Le Dang, Q.; Kim, J.C. Antifungal activity of sterols and dipsacus saponins isolated from Dipsacus asper roots against phytopathogenic fungi. Pestic. Biochem. Physiol. 2017, 141, 103-108. [CrossRef]

39. Yoon, M.Y.; Choi, G.J.; Choi, Y.H.; Jang, K.S.; Park, M.S.; Cha, B.; Kim, J.C. Effect of polyacetylenic acids from Prunella vulgaris on various plant pathogens. Lett. Appl. Microbiol. 2010, 51, 511-517. [CrossRef]

40. Schuster, C.; Konstantinidou-Doltsinis, S.; Schmitt, A. Glycyrrhiza glabra extract protects plants against important phytopathogenic fungi. Commun. Agric. Appl. Biol. Sci. 2010, 75, 531-540.

41. Turóczi, B.; Bakonyi, J.; Szabó, K.A.; Bálint, J.; Máthé, I.; Lányi, S.; Balog, A. In vitro and in vivo effect of poplar bud extracts on Phytophthora infestans: A new effective biological method in potato late blight control. Plants 2020, 9, 217. [CrossRef]

42. Gao, L.; Bradeen, J.M. Contrasting Potato Foliage and Tuber Defense Mechanisms against the Late Blight Pathogen Phytophthora infestans. PLoS ONE 2016, 11, e0159969. [CrossRef]

43. Arafa, R.A.; Rakha, M.T.; Soliman, N.E.K.; Moussa, O.M.; Kamel, S.M.; Shirasawa, K. Rapid identification of candidate genes for resistance to tomato late blight disease using next-generation sequencing technologies. PLoS ONE 2017, 12, e0189951. [CrossRef]

44. Ha, J.H.; Jang, H.A.; Moon, K.B.; Baek, K.H.; Choi, G.J.; Choi, D.; Cho, H.S.; Kwon, S.Y.; Jeon, J.H.; Oh, S.K.; et al. Nicotiana benthamiana Matrix Metalloprotease 1 (NMMP1) gene confers disease resistance to Phytophthora infestans in tobacco and potato plants. J. Plant Physiol. 2017, 218, 189-195. [CrossRef] [PubMed]

45. Natarajan, B.; Kalsi, H.S.; Godbole, P.; Malankar, N.; Thiagarayaselvam, A.; Siddappa, S.; Thulasiram, H.V.; Chakrabarti, S.K.; Banerjee, A.K. MiRNA160 is associated with local defense and systemic acquired resistance against Phytophthora infestans infection in potato. J. Exp. Bot. 2018, 69, 2023-2036. [CrossRef] [PubMed]

46. Kumar, A.; Farooqi, M.S.; Mishra, D.C.; Kumar, S.; Rai, A.; Chaturvedi, K.K.; Lal, S.B.; Sharma, A. Prediction of miRNA and Identification of their Relationship Network Related to Late Blight Disease of Potato. MicroRNA 2017, 7, 11-19. [CrossRef] [PubMed]

47. Niderman, T.; Genetet, I.; Bruyere, T.; Gees, R.; Stintzi, A.; Legrand, M.; Fritig, B.; Mosinger, E. Pathogenesis-related PR-1 proteins are antifungal. Isolation and characterization of three 14-kilodalton proteins of tomato and of a basic PR-1 of tobacco with inhibitory activity against Phytophthora infestans. Plant Physiol. 1995, 108, 17-27. [CrossRef]

48. Hoegen, E.; Strömberg, A.; Pihlgren, U.; Kombrink, E. Primary structure and tissue-specific expression of the pathogenesis-related protein PR-1b in potato. Mol. Plant Pathol. 2002, 3, 329-345. [CrossRef] 
49. Thomas, C.; Mabon, R.; Andrivon, D.; Val, F. The effectiveness of induced defense responses in a susceptible potato genotype depends on the growth rate of Phytophthora infestans. Mol. Plant Microbe Interact. 2019, 32, 76-85. [CrossRef]

50. Belbahri, L.; Calmin, G.; Mauch, F.; Andersson, J.O. Evolution of the cutinase gene family: Evidence for lateral gene transfer of a candidate Phytophthora virulence factor. Gene 2008, 408, 1-8. [CrossRef]

51. Zhang, Y.; Fletcher, K.; Han, R.; Michelmore, R.; Yang, R. Genome-wide analysis of cyclophilin proteins in 21 oomycetes. Pathogens 2020, 9, 24. [CrossRef]

52. Meijer, H.J.G.; Schoina, C.; Wang, S.; Bouwmeester, K.; Hua, C.; Govers, F. Phytophthora infestans small phospholipase D-like proteins elicit plant cell death and promote virulence. Mol. Plant Pathol. 2019, 20, 180-193. [CrossRef]

53. Gvozdeva, E.L.; Ievleva, E.V.; Gerasimova, N.G.; Ozeretskovskaya, O.L.; Valueva, T.A. Exoproteinases of the oomycete Phytophthora infestans. Appl. Biochem. Microbiol. 2004, 40, 165-169. [CrossRef]

54. Boutemy, L.S.; King, S.R.F.; Win, J.; Hughes, R.K.; Clarke, T.A.; Blumenschein, T.M.A.; Kamoun, S.; Banfield, M.J. Structures of Phytophthora RXLR effector proteins: A conserved but adaptable fold underpins functional diversity. J. Biol. Chem. 2011, 286, 35834-35842. [CrossRef] [PubMed]

55. Wawra, S.; Trusch, F.; Matena, A.; Apostolakis, K.; Linne, U.; Zhukov, I.; Stanek, J.; Koźmiński, W.; Davidson, I.; Secombes, C.J.; et al. The RxLR motif of the host targeting effector AVR3a of Phytophthora infestans is cleaved before secretion. Plant Cell 2017, 29, 1184-1195. [CrossRef] [PubMed]

56. S Stajner, D.; Popović, B.M.; Ĉanadanović-Brunet, J.; Anaĉkov, G. Exploring Equisetum arvense L., Equisetum ramosissimum L. and Equisetum telmateia L. as sources of natural antioxidants. Phyther. Res. 2009, 23, 546-550. [CrossRef] [PubMed]

57. Francescato, L.N.; Debenedetti, S.L.; Schwanz, T.G.; Bassani, V.L.; Henriques, A.T. Identification of phenolic compounds in Equisetum giganteum by LC-ESI-MS/MS and a new approach to total flavonoid quantification. Talanta 2013, 105, 192-203. [CrossRef] [PubMed]

58. Patova, O.A.; Smirnov, V.V.; Golovchenko, V.V.; Vityazev, F.V.; Shashkov, A.S.; Popov, S.V. Structural, rheological and antioxidant properties of pectins from Equisetum arvense L. and Equisetum sylvaticum L. Carbohydr. Polym. 2019, 209, 239-249. [CrossRef]

59. Hase, T.; Wada, K.; Matsubara, H. Horsetail (Equisetum arvense) ferredoxins I and II: Amino acid sequences and gene duplication. J. Biochem. 1977, 82, 277-286. [CrossRef]

60. Brumme, S.; Kruft, V.; Schmitz, U.K.; Braun, H.P. New insights into the co-evolution of cytochrome c reductase and the mitochondrial processing peptidase. J. Biol. Chem. 1998, 273, 13143-13149. [CrossRef]

61. Al Mohammed, H.I.; Paray, B.A.; Rather, I.A. Anticancer activity of EA1 extracted from Equisetum arvense. Pak. J. Pharm. Sci. 2017, 30, 1947-1950.

62. Do Monte, F.H.M.; Dos Santos, J.G.; Russi, M.; Bispo Lanziotti, V.M.N.; Moreira Leal, L.K.A.; De Andrade Cunha, G.M. Antinociceptive and anti-inflammatory properties of the hydroalcoholic extract of stems from Equisetum arvense L. in mice. Pharmacol. Res. 2004, 49, 239-243. [CrossRef]

63. Garcia, D.; Ramos, A.J.; Sanchis, V.; Marín, S. Equisetum arvense hydro-alcoholic extract: Phenolic composition and antifungal and antimycotoxigenic effect against Aspergillus flavus and Fusarium verticillioides in stored maize. J. Sci. Food Agric. 2013, 93, 2248-2253. [CrossRef]

64. Wojnicz, D.; Kucharska, A.Z.; Sokół-Łętowska, A.; Kicia, M.; Tichaczek-Goska, D. Medicinal plants extracts affect virulence factors expression and biofilm formation by the uropathogenic Escherichia coli. Urol. Res. 2012, 40, 683-697. [CrossRef] [PubMed]

65. Grégoire, C.; Rémus-Borel, W.; Vivancos, J.; Labbé, C.; Belzile, F.; Bélanger, R.R. Discovery of a multigene family of aquaporin silicon transporters in the primitive plant Equisetum arvense. Plant J. 2012, 72, 320-330. [CrossRef]

66. Inamine, S.; Onaga, S.; Ohnuma, T.; Fukamizo, T.; Taira, T. Purification, cDNA cloning, and characterization of LysM-containing plant chitinase from horsetail (Equisetum arvense). Biosci. Biotechnol. Biochem. 2015, 79, 1296-1304. [CrossRef] [PubMed]

67. Karol, K.G.; Arumuganathan, K.; Boore, J.L.; Duffy, A.M.; De Everett, K.; Hall, J.D.; Hansen, S.K.; Kuehl, J.V.; Mandoli, D.F.; Mishler, B.D.; et al. Complete plastome sequences of Equisetum arvense and Isoetes flaccida: Implications for phylogeny and plastid genome evolution of early land plant lineages. BMC Evol. Biol. 2010, 10, 321. [CrossRef] [PubMed] 
68. Rogozhin, E.A.; Tepkeeva, I.I.; Zaitsev, D.V.; Demushkin, V.P.; Smirnov, A.N. Biological activity of peptide extracts of medicinal plants against phytopathogenic fungi and oomycetes. Russ. Agric. Sci. 2011, 37, 314-317. [CrossRef]

69. Odintsova, T.I.; Vassilevski, A.A.; Slavokhotova, A.A.; Musolyamov, A.K.; Finkina, E.I.; Khadeeva, N.V.; Rogozhin, E.A.; Korostyleva, T.V.; Pukhalsky, V.A.; Grishin, E.V.; et al. A novel antifungal hevein-type peptide from Triticum kiharae seeds with a unique 10-cysteine motif. FEBS J. 2009, 276, 4266-4275. [CrossRef]

70. Odintsova, T.; Rogozhin, E.; Sklyar, I.; Musolyamov, A.; Kudryavtsev, A.; Pukhalsky, V.; Smirnov, A.; Grishin, E.; Egorov, T. Antifungal Activity of Storage 2S Albumins from Seeds of the Invasive Weed Dandelion Taraxacum officinale Wigg. Protein Pept. Lett. 2010, 17, 522-529. [CrossRef]

(C) 2020 by the authors. Licensee MDPI, Basel, Switzerland. This article is an open access article distributed under the terms and conditions of the Creative Commons Attribution (CC BY) license (http://creativecommons.org/licenses/by/4.0/). 